\title{
Hydro-Physical Properties of Soils under Different Land Uses in Northeastern Nigeria
}

\author{
Ibraheem Alhassan ${ }^{1, a, *}$, Muhammad Saddiq Askira ${ }^{2, b}$ \\ ${ }^{1}$ Department of Agronomy, Federal University Gashua, Yobe State, Nigeria \\ ${ }^{2}$ Department of Soil Science, Federal University Kashere, Gombe State, Nigeria \\ *Corresponding author \\ A R T I C L I N F O A B S T R A C T \\ Research Article \\ Evaluation of soil hydro-physical properties is very important in agriculture and for sustainable \\ management of the land resources. This investigation was conducted to assess some hydro-physical \\ properties of soils in different land use types (LUT) selected (i.e., dry upper land (UD), lowland \\ (LL) and residential area (RA)) at $0-15 \mathrm{~cm}$ and $15-30 \mathrm{~cm}$ depths in Bade Local Government Area of \\ Received : 06/04/2021 \\ Accepted : 04/08/2021 \\ Northeastern, Nigeria. Soils were randomly sampled at four points in each LUT and analyzed \\ according to standard soil analysis procedures. Results of the analyses of variance showed that LL \\ had recorded significantly higher clay content, larger soil porosities and high-water retention \\ properties than the other LUT. Soil structural stability index (SSI) and organic carbon (OC) were \\ below optimal range and statistically not different across the land uses. The results also indicated \\ non-significant differences in the hydro-physical properties within the sampling depths. The \\ coefficient of variation $(\mathrm{CV})$ revealed that, slight variation $(\mathrm{CV}<15 \%)$ in the distribution of sand \\ fraction, bulk density, total porosity, macroporosity, microporosity, saturation percentage, field \\ capacity, permanent wilting point and plant available water while, silt (16.59\%), clay (20.00\%), SSI \\ $(33.75 \%)$ and OC $(33.62 \%)$ varied moderately (CV 15-35\%). The LUT studied have very weak \\ soil structure, therefore specific management practices that will sustain their usage should be \\ adopted.

\begin{tabular}{|c|c|}
\hline $\begin{array}{l}\text { Keywords: } \\
\text { Gashua } \\
\text { Loamy sand } \\
\text { Soil porosity } \\
\text { Soil texture } \\
\text { Water retention }\end{array}$ & $\begin{array}{l}\text { non-significant differences in the hydro-physical properties within the sampling depths. The } \\
\text { coefficient of variation (CV) revealed that, slight variation }(\mathrm{CV}<15 \%) \text { in the distribution of sand } \\
\text { fraction, bulk density, total porosity, macroporosity, microporosity, saturation percentage, field } \\
\text { capacity, permanent wilting point and plant available water while, silt }(16.59 \%) \text {, clay }(20.00 \%) \text {, SSI } \\
(33.75 \%) \text { and OC }(33.62 \%) \text { varied moderately }(\mathrm{CV} 15-35 \%) \text {. The LUT studied have very weak } \\
\text { soil structure, therefore specific management practices that will sustain their usage should be } \\
\text { adopted. }\end{array}$ \\
\hline
\end{tabular}

\section{Introduction}

Assessing the hydrophysical characteristics of soils is very important in establishing soil quality, with regard to water retention, texture, organic matter content, and biophysicochemical properties (Pires Luiz et al., 2017; Rabot et al., 2018). The hydrophysical parameters of the soil are also closely related to movement of nutrients, toxic elements and even their transfer to plants (Rieuwerts et al., 2018). They affect the quantity and rate of water, oxygen, and nutrient absorption by plants as well as the ability of the soil to supply it to the roots and it had been asserted that these properties play a crucial role in determining soil's suitability for agricultural, environmental and engineering uses which are directly related to physical properties of the soil (Phogat et al., 1999).

The importance of soil physical properties is a central concept for quantifying land degradation and developing appropriate land management practices. Soils with excellent physical properties should have indicator values which fall within the optimal ranges, or at least not beyond the critical limits, for maximized crop performance, and minimized soil and environmental degradation (Mueller et al., 2008). The importance of critical soil parameters like bulk density, relative field capacity, plant-available water capacity, air capacity, macro porosity, organic carbon content and structural stability index that quantify the level or degree of quality as well as the nature and influence of these physical properties on soil-plant atmosphere had been reported (Reynolds et al., 2009).

The need for more information about the status of physical properties of soils under different land uses was supported by the report that tropical landscapes are rapidly changing due to anthropogenic activities. High attention on monitoring these changes in tropical resources are being placed now by international communities (Tellen and Yerima, 2018). A number, of the physical properties reported to have been affected by land use types activities were the significant changes noticed in soil bulk density, porosity and water retention and intake characteristics (Dionizio and Costa, 2018).

The soil physical properties like texture, structure and bulk density were found to have direct effect on some other physical properties of the soils. Differences in soil texture 
and structure determine pore size distribution and water retention properties (saturation percentage, field capacity, and permanent wilting point); of the soils for instance sandy soils in the tropics showed a large range of porosities and consequently bulk density; the porosity ranges from $33 \%$ to $47 \%$ are commonly recorded and are usually smaller than in clayey and silty soils (O'Geen, 2013; Zotarelli et al., 2019). Soil organic carbon content (OC), as a primarily indicator of soil chemical and biological quality, also have strong indirect effects on soil physical quality (Shukla et al., 2006). The importance of soil water retention and availability for agricultural production was stressed (Bortolini and Albuquerque, 2018) which are often measured directly or estimated by pedotransfer functions. Accurate determination of soil-water status (either matric potential or water content) is not only important for irrigation and water resources management, it's also a fundamental element of soil-water movement, chemical (fate) transport, crop water stress, evapotranspiration, hydrologic and crop modeling, climate change, and other important disciplines (Irmak, 2019).

Soil physical degradation has been one of the major agricultural production problems within the Sahelian region (Doso, 2014; Macaulay, 2014) and in spite of enormity of the problem only very scanty data were available on the hydro-physical conditions of the soils of the study area. Therefore, this investigation was undertaken to evaluate the effect of various landuse types on some soil hydro-physical properties in Bade Local Government Area of Yobe State, North Eastern Nigeria to bridge a knowledge gap existing in that regard and have background information for further research.

\section{Materials and Methods}

The study was conducted between August and October, 2018 at Gashua in Bade Local Government Area of Yobe State, Northeast Nigeria. It is situated $190 \mathrm{~km}$ Northwest of Damaturu, the State Capital. It is located between latitudes $12.874^{\circ} \mathrm{N}$, and longitudes $11.0406^{\circ} \mathrm{E}$, at an average altitude of 293 meters above sea level. Geologically, the study area is covered principally of sedimentary rocks, underlain by basement complex rocks. Sedimentary formations were uncomfortably overlaid by a large expanse of Quaternary Chad formation. However, the influence of climatic change is reflected in the superficial deposits overlaying most of the northern part of Yobe State. This has led to the deposition of series of Aeolian materials. The majority of the soils in the study area are Alfisols and lixisols that are fine sandy loam in texture. It is a representative of the Sahel savanna agro-climatic zone with a unimodal rainfall pattern of an average annual rainfall of $300-500 \mathrm{~mm}$ and maximum rain is received between August and September. The annual mean minimum and mean maximum temperatures at the study area are 12 and $44^{\circ} \mathrm{C}$ respectively. The dominant vegetal cover is sparse and sahelian, comprising mostly of grasses growing in individual tufts leaving bare surfaces in between and the typical trees include the acacia, doum palm, silk cotton, neem, and baobab (NEAZDP, 2015: Jalloh et al., 2011).

Gashua is one of the major commercial and agricultural/fish markets in Yobe State. Economic activities of the communities are relatively diverse but, agriculture and fishing constitute more than $73.1 \%$ of the economic activity of the area which lies near the NguruGashua Wetlands, an area playing a major role in the regional economic. The area supports irrigated farming, fisheries and animal husbandry. Arable farms are intensively cultivated for staple food crops such as millet, sorghum, rice, cowpea and sesame (Babagana et al., 2018; Ogunkoya and Dami, 2007).

Three major land use types in the area selected are: dry upland (DU) mostly comprised of cereal crops farms; Lowland (LL) are mostly use for vegetable and irrigation farming along river Yobe floodplain and Residential land (RA) within human settlements.

Four auger soil samples were collected at $0-15$ and 15$30 \mathrm{~cm}$ depths from each field at random, making a total of eight samples for each LUT. The samples were thoroughly mixed separately and passed through $2 \mathrm{~mm}$ sieve for laboratory analysis (particle size and organic carbon analyses). Undisturbed core samples were also collected close to each of the four auger points in each field using core sampler for bulk density, porosity and water retention properties determinations.

Particle size was determined by the hydrometer method and textural classes determined from textural triangle, organic carbon (OC) content was determined according to the Walkley-Black wet oxidation method and then bulk density ( $\mathrm{Db}$ ) was determined using undisturbed core sampler method using volumetric cylinder and calculated by dividing the oven dry mass at $105^{\circ} \mathrm{C}$ (Estefan et al., 2013).

$$
\text { Bulk density }(\mathrm{Db})=\frac{\mathrm{Ms}}{\mathrm{Vt}}
$$

$$
\begin{aligned}
& \text { Where; } \\
& \mathrm{Ms}=\text { is the oven- dried soil mass } \\
& \mathrm{Vt}=\text { volume of the soil core sampler. }
\end{aligned}
$$

Soil Structural Index (SSI) was calculated as described in Reynolds et al. (2009) as follows:

$$
\text { SSI }(\%)=\frac{1.724 \times \% \mathrm{OC}}{\% \text { Silt }+\% \text { Clay }} \times 100
$$

The total porosity (TP) was estimated as described in Estefan et al. (2013) as:

$$
\mathrm{TP}(\%)=\left[1-\left(\frac{\mathrm{Db}}{\rho \mathrm{s}}\right)\right] \times 100
$$

In equation Eq.3; $\mathrm{TP}=$ total porosity, $\rho \mathrm{b}=$ bulk density, $\rho s=$ particle density (average value of $2.65 \mathrm{~g} \mathrm{~cm}^{-3}$ is used as particle density). According to Pagliai (2010) when total porosity $(\mathrm{TP})<5 \%=$ very compact soil $; 5-10 \%=$ compact soil; $10-25 \%=$ moderately porous; $25-40 \%=$ highly porous and $>40 \%=$ extremely porous (Pagliai, 2010).

Macroporosity (Pmacro) and Microporosity (Pmicro) were calculated as described in Malgwi and Abu (2011):

$$
\begin{aligned}
& \text { Pmacro }(\%)=\mathrm{TP}-\mathrm{FC} \\
& \text { Pmicro }(\%)=\mathrm{TP}-\text { Pmacro }
\end{aligned}
$$


The core sample was taken when the soils were saturated for saturation percentage (SP) determination using the following procedure expressed in Mbah (2012) as follows:

$$
\mathrm{SP}(\%)=\frac{\mathrm{K}-\mathrm{J}}{\mathrm{J}-\mathrm{C}} \times 100
$$

In Eq.6: J = weight of crucible + dry sample, $\mathrm{C}=$ weight of crucible only. $\mathrm{K}=$ weight of crucible + wet sample.

Field capacity (FC), permanent wilting point (PWP) and plant available water (PAW) were determined by saturation water percentage-based estimation models of Mbagwu and Mbah (1998) as:

$$
\begin{aligned}
& \mathrm{FC}(\%)=0.79(\mathrm{SP})-6.22(\mathrm{r}=0.972) \\
& \operatorname{PWP}(\%)=0.51(\mathrm{SP})-8.65(\mathrm{r}=0.949) \\
& \text { PAW }(\%)=\mathrm{FC}-\mathrm{PWP}
\end{aligned}
$$

All data were statistically analyzed to determine the variation in soil properties using the coefficient of variation (CV) as rating (Tabi and Ogunkunle, 2007). Statistical differences in measured soil characteristics among land use types and sampling depth were analyzed by a one-way analysis of variance (ANOVA) at 5\% significance levels and graphical presentations with $\mathrm{R}$ version 3.6.3 statistical package ( $\mathrm{R}$ core, 2019).

\section{Results and Discussion} (SSI)

Particle Size Distribution and Soil Structural Index

There were significant differences in sand $(\mathrm{P}=0.0007)$ and clay $(\mathrm{P}=0.0002)$ particle size distribution as influenced by the land use types (Table 1$)$. The Silt (16.59\%) and clay $(20.00 \%)$ fractions showed moderate variation within the land uses while, sand indicated low variability (4.63\%). The highest average clay content was recorded under lowland (LL) $(17.38 \%)$ and the lowest in the residential area (RA) (11.25\%), this might be attributed to the seasonal flooding which may likely deposited clay on soil the surface in the low land areas. The sand content recorded under RA was significantly higher $(71.75 \%)$ at par with the sand content in dry upper land (DU) (71.50\%). Generally, the textural class of the soils of the study areas is sandy loam. This conformed to the findings of Shehu et al. (2015) who reported that $80 \%$ of the soils of some selected fields in a savanna zone of northern Nigeria had sandy loam on surface $(0-20 \mathrm{~cm})$ and sub-surface $(20-40 \mathrm{~cm})$ and that the dominance of sand contents in Northern Nigerian soils is as a result of sorting of materials by clay eluviation and surface wind erosion (Voncir et al., 2008). No significant difference was observed within the different soil depth in sand, silt and clay fractions, with all having sandy loam textural classes. This agrees with the findings of Nabayi et al. (2020) in similar environment (Table 1).

The mean SSI found within the soils was greater in LL (6.28), RA (6.24) and lower in DU (5.65), there was no statistical differences between the land use types (Table 1). The values indicate high risk structural degradation (Reynolds et al., 2009) which can require some management practices which will improve on the organic matter content of the soil, since SSI estimation was based on OC and texture. Lower level of organic $\mathrm{C}$ with a high percentage of sand particles was found to results in poor physical stability of the soils (Salako, 2003).

\section{Soil Bulk Density (Db), Porosities and Organic Carbon (OC)}

The average $\mathrm{Db}$ values of the soils under different land use types were found to significantly differ $(P=0001)$ with higher value in RA $\left(1.61 \mathrm{~g} \mathrm{~cm}^{-3}\right)$ followed by $\left(1.60 \mathrm{~g} \mathrm{~cm}^{-3}\right)$ in DU and lower in LL $\left(1.54 \mathrm{~g} \mathrm{~cm}^{-3}\right)$ as presented in Table 2. The values recorded are within the suitable range for plant growth, while the relatively higher values of $\mathrm{Db}$ obtained might be attributed to the trampling effect of varied human activities in RA. This result is in agreement with the USDA (2017) that poorly aggregated soil usually has low OC and high bulk density.

Significant differences were found between the land use types within the soil total porosity $(\mathrm{P}=0001)$, macroporosity $(\mathrm{P}=0034)$ and microporosity $(\mathrm{P}=0002)$. Significantly higher values of $42.07 \%, 15.85 \%$ and $26.22 \%$ were recorded in LL for total porosity, macroporosity and microporosity respectively, while lower values were found in RA statistically at par with those in DU (Table 2). The TP results showed that each one of the soils from the studied land use type were highly porous (Pagliai, 2010). The implication of highly porous soil is that it will require frequent irrigation if subjected to irrigation agriculture or the structure be improved through addition of organic manure and crop residues. Very low coefficients of variability were recorded in all the measured porosities (Table 2). The macroporosity across the landuses did not fall below the $10 \%$ critical limit

\begin{tabular}{|c|c|c|c|c|c|}
\hline & Sand (\%) & Silt (\%) & Clay $(\%)$ & Textural Class & SSI (\%) \\
\hline \multicolumn{6}{|c|}{ Landuse } \\
\hline$\overline{D U}$ & $71.50^{\mathrm{a}}$ & 16.88 & $11.62^{b}$ & SL & 3.28 \\
\hline LL & $65.25^{\mathrm{b}}$ & 17.38 & $17.38^{\mathrm{a}}$ & SL & 3.64 \\
\hline RA & $71.75^{\mathrm{a}}$ & 17.00 & $11.25^{\mathrm{b}}$ & SL & 3.62 \\
\hline $\mathrm{SE}$ & 1.61 & 1.42 & 1.34 & & 0.59 \\
\hline $\operatorname{Pr}(>F)$ & 0.007 & 0.935 & 0.0002 & & 0.7919 \\
\hline $\mathrm{CV}(\%)$ & 4.63 & 16.59 & 20.00 & & 33.75 \\
\hline \multicolumn{6}{|c|}{ Depth } \\
\hline $0-15 \mathrm{~cm}$ & 69.00 & 17.17 & 13.83 & SL & 3.67 \\
\hline $15-30 \mathrm{~cm}$ & 70.00 & 17.00 & 13.00 & SL & 3.36 \\
\hline SE & 1.80 & 1.13 & 1.59 & & 0.47 \\
\hline $\operatorname{Pr}(>F)$ & 0.5843 & 0.8845 & 0.6065 & & 0.5175 \\
\hline CV (\%) & 6.35 & 16.26 & 29.11 & & 33.02 \\
\hline
\end{tabular}
adequate for plant growth (Bergamin et al., 2015), as such aeration deficit might not be a problem in these soils.

Table 1. Mean values of soil texture and structural index under different land uses

DU = Dry Upland, LL = Lowland, RA = Residential Area, SL = Sandy loam, SSI = Soil Structural Index, SE = Standard Error, CV = Coefficient of variation, means with the same letter are not significantly different. 
Table 2. Mean values of soil bulk density, porosities and organic carbon content under different land uses

\begin{tabular}{|c|c|c|c|c|c|}
\hline & $\mathrm{Db}\left(\mathrm{g} \mathrm{cm}^{-3}\right)$ & TP (\%) & Pmacro (\%) & Pmicro (\%) & $\mathrm{OC}(\%)$ \\
\hline \multicolumn{6}{|c|}{ Landuse } \\
\hline DU & $1.60 \mathrm{a}$ & $39.72 b$ & $14.87 \mathrm{~b}$ & $24.85 b$ & 0.55 \\
\hline LL & $1.54 \mathrm{~b}$ & $42.07 \mathrm{a}$ & $15.85 \mathrm{a}$ & $26.22 \mathrm{a}$ & 0.72 \\
\hline RA & $1.61 \mathrm{a}$ & $39.05 b$ & $14.66 \mathrm{~b}$ & $24.39 \mathrm{~b}$ & 0.59 \\
\hline SE & 0.01 & 0.50 & 0.33 & 0.37 & 0.10 \\
\hline $\operatorname{Pr}(>F)$ & 0.0001 & 0.0001 & 0.0034 & 0.0002 & 0.2756 \\
\hline $\mathrm{CV}(\%)$ & 1.67 & 2.48 & 4.34 & 2.92 & 33.62 \\
\hline \multicolumn{6}{|c|}{ Depth } \\
\hline $0-15 \mathrm{~cm}$ & 1.58 & 40.41 & 15.11 & 25.30 & 0.65 \\
\hline $15-30 \mathrm{~cm}$ & 1.59 & 40.16 & 15.15 & 25.01 & 0.59 \\
\hline SE & 0.02 & 0.68 & 0.34 & 0.44 & 0.09 \\
\hline $\operatorname{Pr}(>F)$ & 0.7147 & 0.7162 & 0.9215 & 0.5232 & 0.4598 \\
\hline $\mathrm{CV}(\%)$ & 2.79 & 4.13 & 5.55 & 4.27 & 34.49 \\
\hline
\end{tabular}

DU = Dry Upland, LL $=$ Lowland, RA $=$ Residential Area, BD $=$ Soil Bulk Density, TP $=$ Total Porosity, Pmacro = Macroporosity, Pmicro $=$ Microporosity, $\mathrm{OC}=$ Organic carbon, $\mathrm{SE}=$ Standard Error, $\mathrm{CV}=$ Coefficient of variation, means with the same letter are not significantly different.

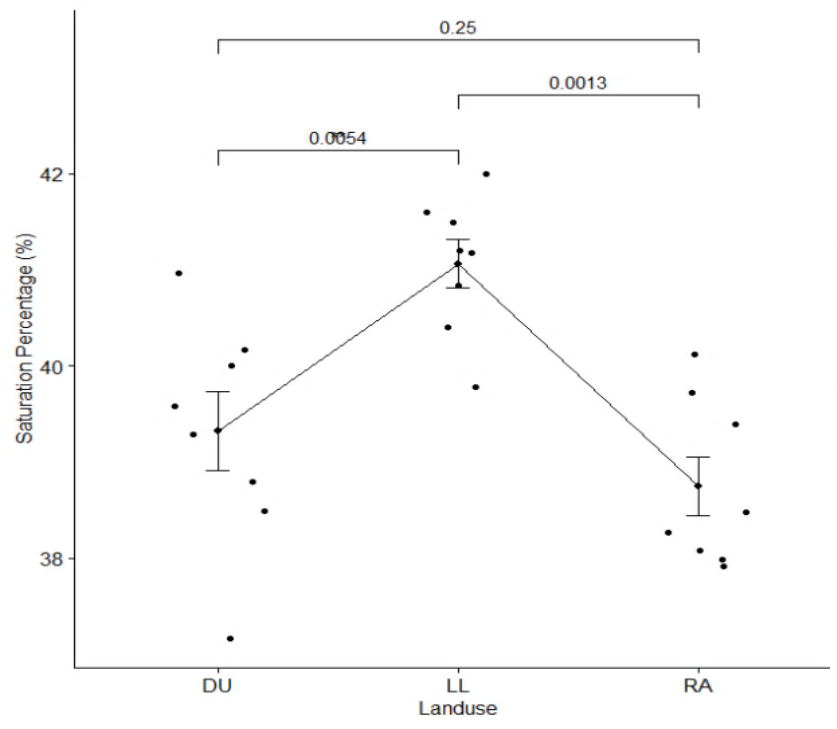

Figure 1A. Mean saturation percentage (\%) under different land uses

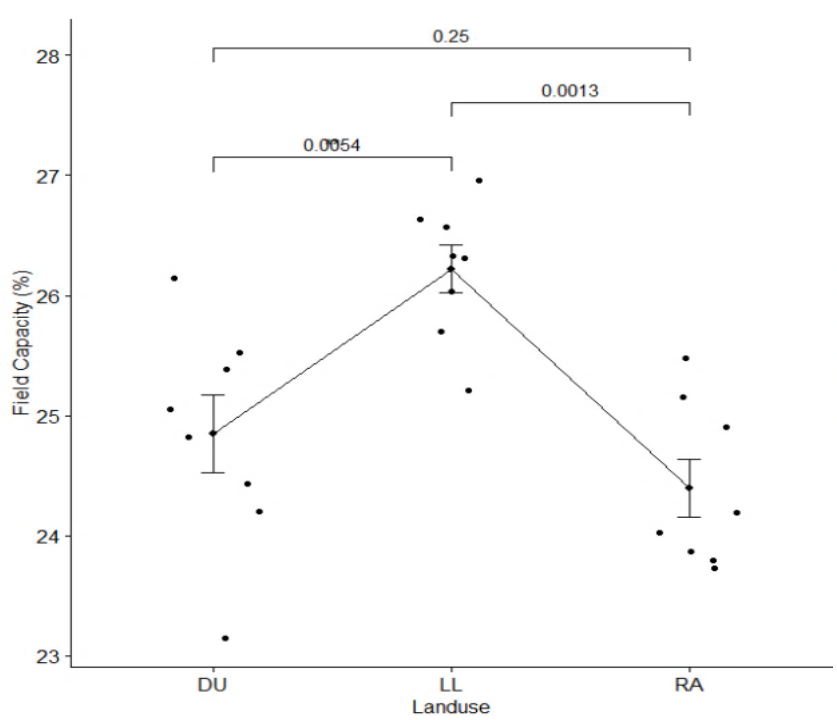

Figure 2A. Mean field capacity (\%) under different Landuses

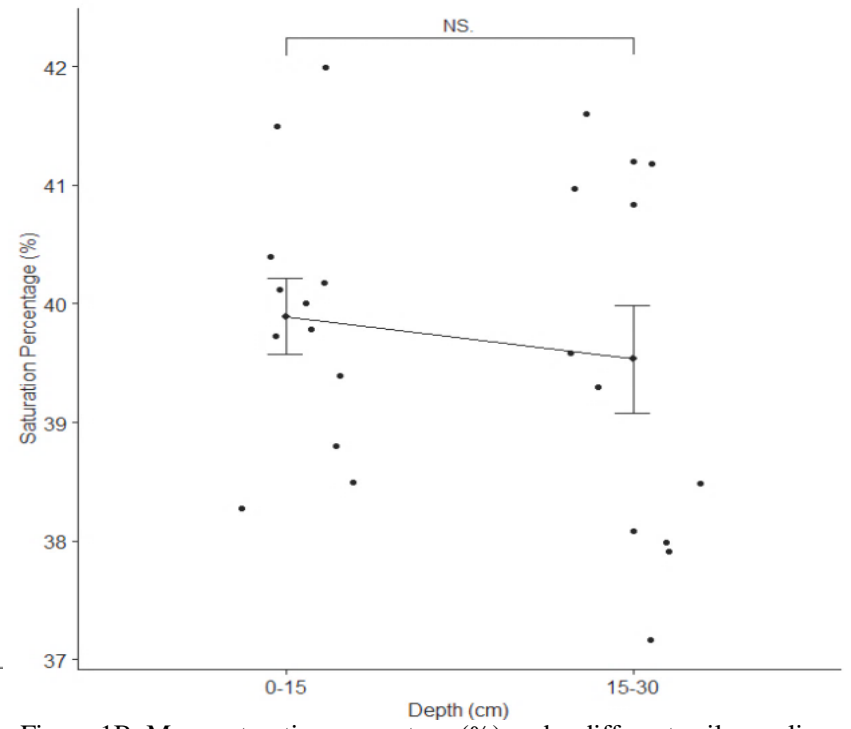

Figure 1B. Mean saturation percentage $(\%)$ under different soil sampling depths

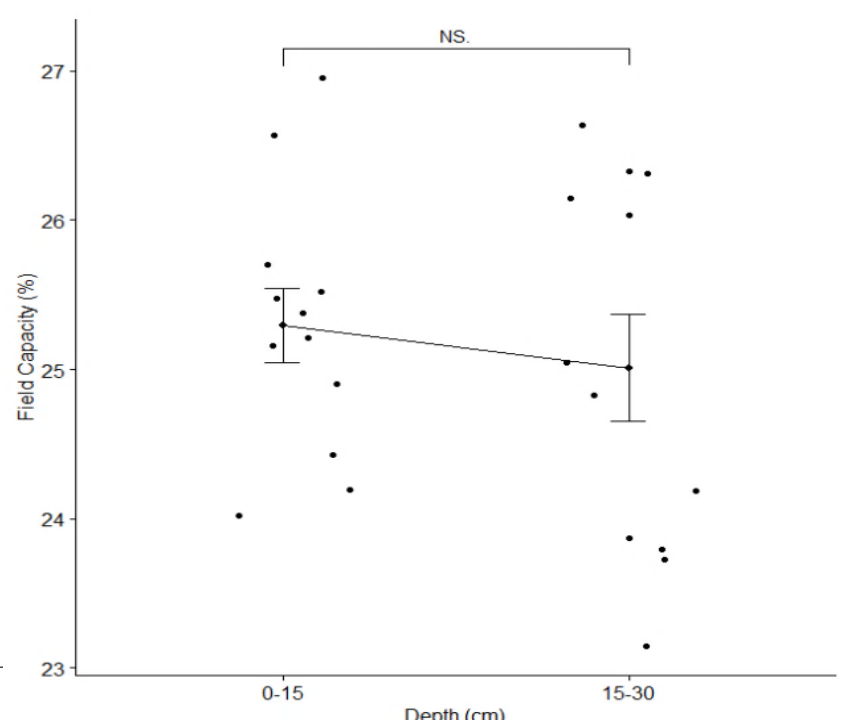

Figure 2B. Mean field capacity (\%) under different soil sampling depths 


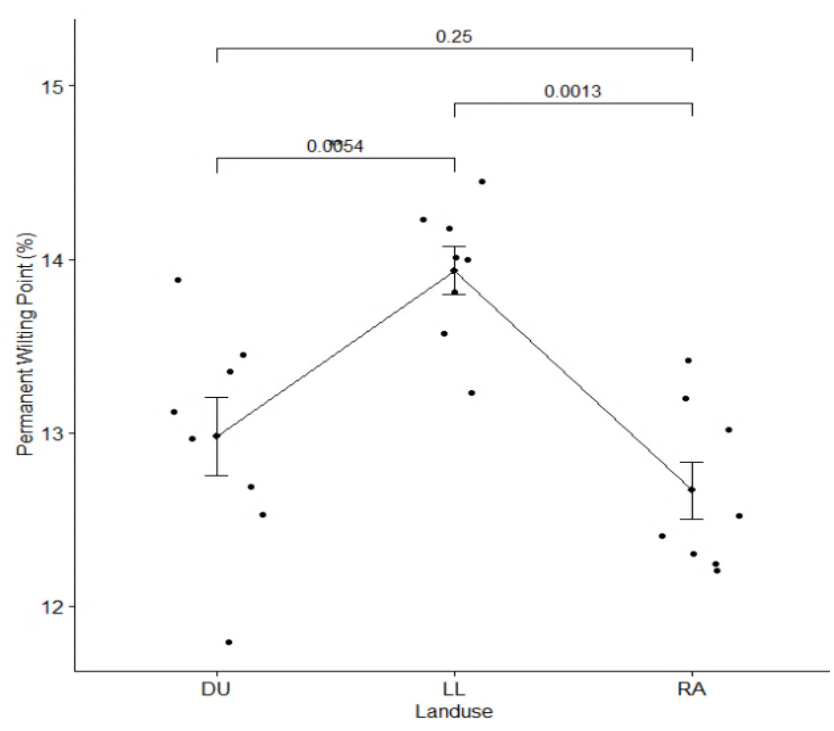

Figure 3A. Mean permanent wilting point (\%) under different land uses

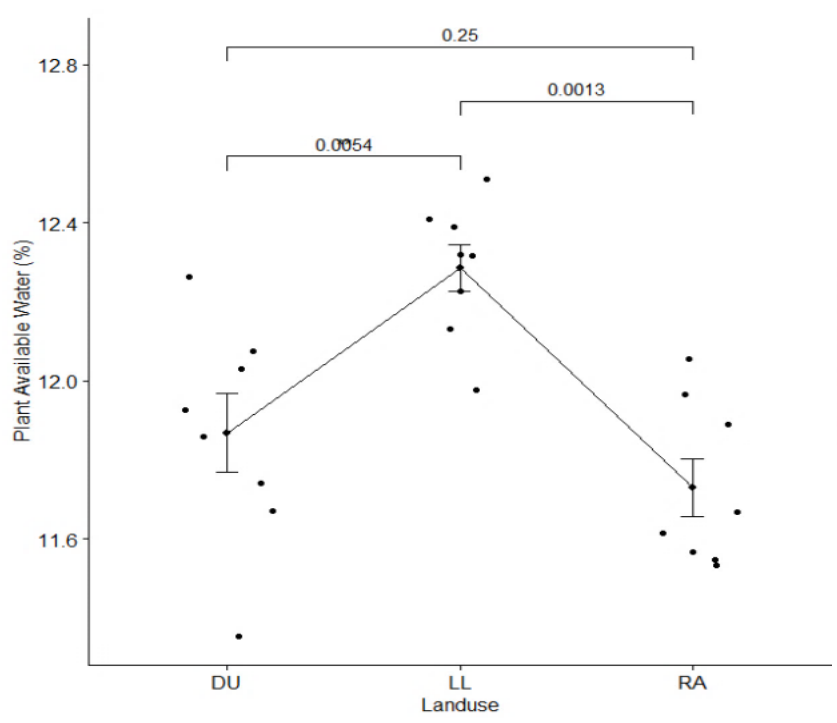

Figure 4A. Mean plant available water $(\%)$ under different landuses

The results showed that OC did not significantly vary with land use types and soil sampling depths $(P=0.2756)$ and $(\mathrm{P}=0.4798)$ respectively but large variation existed across the various land uses and sampling depths (Table 2). Generally, OC content within the soils were considered low in agreement with Shehu et al. (2018) who reported very low level of OC in some Northern Nigerian Savanna soils and Ande et al. (2016) who reported less than $0.8 \%$ OC within the top $30 \mathrm{~cm}$ in Southern Guinea Savanna of North Central Nigeria. Bationo and Buerkert (2001) reported $0.4 \%$ as a mean concentration of organic carbon within the topsoil of an area in Sudan zone and $0.2 \%$ for the Sahel zone and further opined that the soils in the Sudano-Sahelian zone are inherently low in OC. In another report in more than $73.0 \%$ of the fields surveyed in Sudan savanna of Nigeria soil OC level falls into the very low class (Shehu et al., 2015).

\section{Soil Water Retention Properties}

The soil water retention at saturation percentage (SP) significantly varied $(\mathrm{P}=0.0002)$ between the studied land uses with significantly higher mean $(41.06 \%)$ recorded at

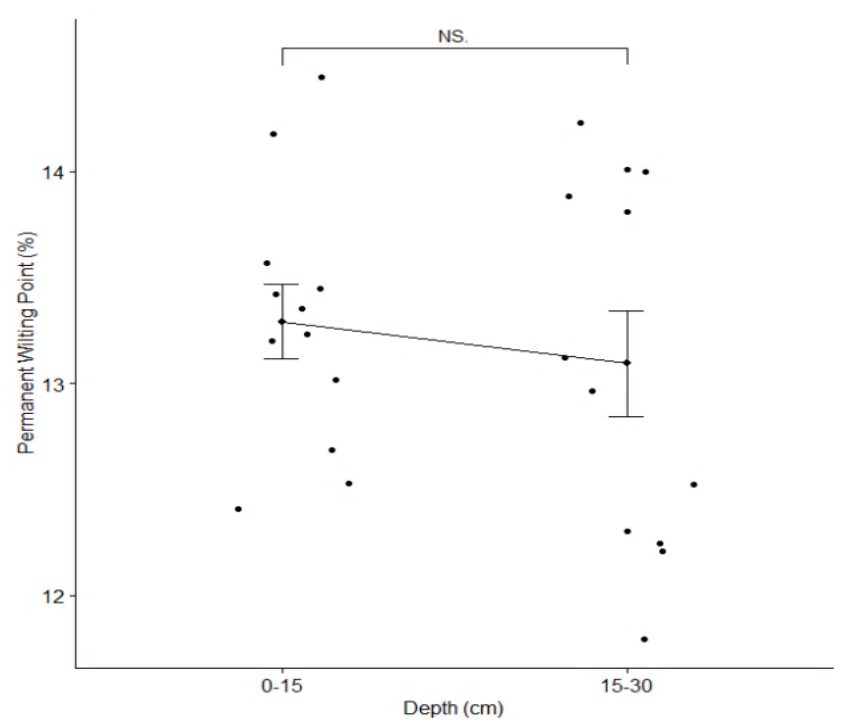

Figure 3B. Mean permanent wilting point (\%)different soil sampling depths

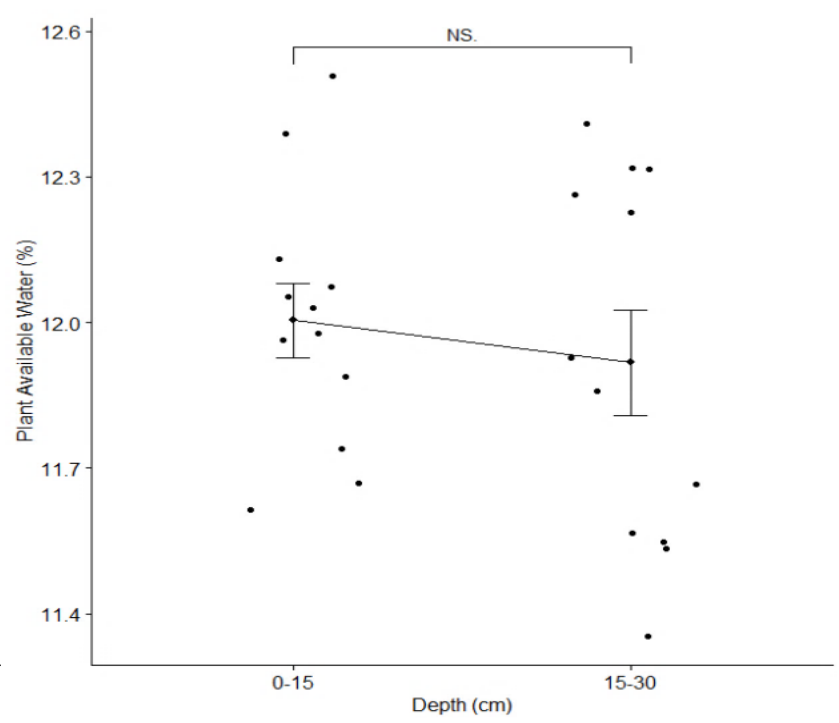

Figure 4B. Mean plant available water (\%) under different soil sampling depths

LL and lower at RA and DU which were at par (Figure 1A). SP was not significantly affected by the soil sampling depth (Figure 1B).

The FC and PWP of the soils showed significant differences between the three land uses with significantly higher mean values $(26.22 \%$ and $13.94 \%)$ recorded under LL compared to the lower values obtained under RA and DU as in SP (Figure 2A and 3A). Onwuegbunam et al. (2019) has reported field capacity (20.7 and 22.1\%) and permanent wilting point (9.0 and $8.9 \%$ ) moisture levels for surface and sub-surface sandy loam soils in northern guinea savanna of Nigeria respectively, while Oguike and Onwuka (2017) reported higher values of 32.3 and $32.8 \%$ for FC in a sandy loam soil at the two depths of $0-20$ and $20-40 \mathrm{~cm}$ in eastern Nigeria. The soil sampling depths did not significantly affect the soil water at FC and PWP significantly (Figure 2B and 3B).

The PAW showed significantly differences across the studied land uses (Figure 4A) with significantly higher value recorded under LL $(12.29 \%)$ in comparison to the lower values in RA (11.73\%) and DU (11.87\%) which are at par. The recorded values within the land uses were 
found to be below the optimal range of $\geq 15.0 \%$ (Reynolds et al. 2009). The implication is that these soils may require supplementary irrigation to meet up to the required level of PAW. There was no significant difference between the surface and sub-surface soil in PAW (Figure 4B). This is in agreement of Shehu et al. (2016) and Malgwi and Abu (2011) who reported PAW below the optimal range of $\geq 15.0 \%$ for soils of northern Nigerian savanna zone.

\section{Conclusions}

The soils of study area were found to be sandy loam in texture, moderate in bulk density, low in organic carbon, structural stability and plant available water retention capacity. Significant variations were observed in most of soil hydro-physical properties under selected land use types within the study area. Higher and favorable values of clay content, saturation percentage, field capacity, wilting point and available water for the soils were observed in lowland; while lower values were observed in upland followed by residential areas. Intensive cultivation, traffic and poor management practices have promoted the loss of soil structural quality in upland and homestead areas. Incorporation of organic matter, good tillage and other sustainable management practices should be taken to improve on the soil hydrophysical parameters.

\section{References}

Ande OT, Are KS, Adeyolanu OD, Ojo OA, Oke AO, Adelana AO, Adetayo AO, Oluwatosin GA. 2016. Characterization of floodplain soils in Southern Guinea Savanna of North Central Nigeria. Catena 139:19-27.

Babagana M, Adamu A, Usman DD, Amma HA, Ado G, Yakubu M, Zungum IU. 2018. Characteristics and SocioEconomic Activities of Local Communities Living Along the Nguru Wetlands, Yobe State, Nigeria. International Journal of Contemporary Research and Review. 9(6): 20224-20239. https://doi.org/10.15520/ijcrr/2018/9/06/528

Bationo A, Buerkert A. 2001. Soil organic carbon management for sustainable land use in Sudano-Sahelian West Africa. Nutrient Cycling in Agroecosystems 61:131-142.

Bergamin AC, Vitorino ACT, Souza FR, Venturoso LR, Bergamin LLP, Campos MCC. 2015. Relationship of soil physical quality parameters and maize yield in a Brazilian Oxisol. Chilean Journal of Agricultural Research 75(3):357365.

Bortolini D, Albuquerque JA. 2018. Estimation of the retention and availability of water in soils of the state of Santa Catarina. Revista Brasileira de Cienca do Solo. doi.org/10.1590/ 18069657rbcs20170250

Doso S. 2014. Land degradation and agriculture in the Sahel of Africa: causes, impacts and recommendations. Journal of Agricultural Science and Applications 3(3):67-73. doi: 10.14511/jasa.2014.030303

Dionizio EA, Costa MH. 2018 Influence of Land Use and Land Cover on Hydraulic and Physical Soil Properties at the Cerrado Agricultural Frontier. Agriculture 9(24):1-14. doi:10.3390/agriculture9010024

Estefan G, Sommer R, Ryan J. 2013. Methods of soil, plant, and Water Analysis: A manual for the West Asia and North Africa region. ICARDA, p.243.

Irmak S. 2019. Soil Water Content- and Soil Matric PotentialBased Irrigation Trigger Values for Different Soil Types. Nebraska Extension NebGuide 3045.
Jalloh A, Rhodes ER, Kollo I, Roy-Macauley H, Sereme P. 2011. Nature and management of the soils in West and Central Africa: A review to inform farming systems research and development in the region. Conseil Ouest et Centre Africain pour la Recherche et le Development Agricoles/West and Central African Council for Agricultural Research and Development (CORAF/WECARD). CORAF/WECARD, Dakar, Senegal.

Macaulay BM. 2014. Land degradation in Northern Nigeria: The impacts and implications of human-related and climatic factors. African Journal of Environmental Science and Technology 8(5):267-273. doi: 10.5897/AJEST2013.1584

Malgwi WB, Abu ST. 2011. Variation in Some Physical Properties of Soils Formed on a Hilly Terrain under Different Land use Types in Nigerian Savanna. International Journal of Soil Science 6(3):150-163.

Mbah CN. 2012. Determining the Field Capacity, wilting point and Available Water Capacity of some Southeast Nigerian Soils using Soil Saturation from Capillary Rise. Nigerian Journal of Biotechnology 24:41-47.

Mbagwu JSC, Mbah CN. 1998. Estimating water retention and availability of soils from their saturation percentage. Communication in Soil Science and Plant Analysis 29:913922.

Mueller L, Kay BD, Been B, Hu C, Zhang Y, Wolff M, Eulenstein F, Schindler U. 2008. Visual assessment of soil structure: Pat II. Implications of tillage, rotation and traffic on sites in Canada, China, and Germany. Soil Tillage Research 103: 188-196

Nabayi A, Santuraki HA, Girei AH, Hayatu NG, Haruna FD, Yusif SA. 2020. Soil structure indices under different tillage systems of sandy loam soil in Hadejia, Jigawa State, Nigeria. Agricultural Science and Technology 12(1):71-76. doi: 10.15547/ast.2020.01.013.

North East Arid Zone Development Programme [NEAZDP]. 2015. Meteorological Data of Nine Local Government Areas in Northern Yobe State, 1992 - 2014 data. NEAZDP Hydromet station, Garin Alkali, Yobe State, Nigeria

O'geen AT. 2013. Soil Water Dynamics. Nature Education Knowledge 4(5):9.

Oguike PC, Onwuka BM. 2017 Variations in Texture, Water Retention and Transmission, Organic Matter and $\mathrm{pH}$ of Soils under Selected Land Use Systems at Ubakala Umuahia, South-Eastern Nigeria. Journal of Scientific and Engineering Research 4(7):147-155.

Ogunkoya OO, Dami A. 2007. Information Sheet on Ramsar Wetlands. Dagona Sanctuary Lake, NG1753RIS (accessed on $1^{\text {st }}$ August, 2021 from https://rsis.ramsar.org).

Onwuegbunam DO, Zakka EJ, Igbadun HE, Oyebode MA. 2019. Calibration and Evaluation of a Moisture Monitoring Meter in two Soil Types of the Northern Guinea Savanna of Nigeria. National Engineering Conference 2018, Ahmadu Bello University, Zaria, Nigeria, 719-722

Pagliai M. 2010. The Soil Pore System as an Indicator of Soil Quality. In: College on Soil Physics: Soil Physical Properties and Processes under Climate Change, no. 2163-3. The Abdussalam International Centre of Theoretical Physics, 30 August to 10 September, 2010, p.23.

Phogat VK, Tomar VS, Dahiya R. 2015. Soil Physical Properties. In. Rattan RK, Katyal JC, Dwivedi BS, Sarkar AK, Bhattachatyya T, Tarafdar JC, Kukal SS. (Eds.): Soil Science: An Introduction, $1^{\text {st }}$.ed. Indian Society of Soil Science, 135171.

Pires Luiz F, Borges Jaqueline,AR, Rosa Jadir A, Cooper M, Heck RJ, Passoni S, Roque WL. 2017. Soil structure changes induced by tillage systems. Soil Tillage Res.165: 66-79.

Rabot E, Wiesmeier M, Schlüter S, Vogel HJ. 2018. Soil structure as an indicator of soil functions: A review. Geoderma. 314:122-137. 
R Core Team. 2019. R: A language and environment for statistical computing. R Foundation for Statistical Computing, Vienna, Austria. URL https://www.R-project.org/.

Reynolds WD, Drury CF, Tan CS, Fox CA, Yang XM. 2009. Use of indicators and pore volume-function characteristics to quantify soil physical quality. Geoderma 152:252-263.

Rieuwerts JS, Thorton I, Farago ME, Ashmore MR. 2015. Factors influencing metal bioavailability in soils: Preliminary investigations for the development of a critical loads for metals. Chem. Spec. Bioavailab. 10:60-75.

Salako FK. 2003. Soil physical conditions in Nigerian savannas and biomass production. Lecture Given at College on Soil Physics Trieste, March 2003, Abeokuta, Nigeria, p.364-377, 2003.

Shehu BM, Jibrin JM, Samndi AM. 2015. Fertility Status of Selected Soils in the Sudan Savanna Biome of Northern Nigeria. International Journal of Soil Science 10(2):74-83. doi: 10.3923/ijss.2015.74.83

Shehu BM, Ogunwale JO, Jibrin JM. 2016. Physical quality of Northern Nigerian Savanna Alfisol: Influence of Jatropha curcas L. and other land use systems, Cogent Food and Agriculture 2. doi:10.1080/23311932.2016.1205272

Shehu BM, Merckx R, Jibrin JM, Kamara AY, Rurinda J. 2018. Quantifying Variability in Maize Yield Response to Nutrient Applications in the Northern Nigerian Savanna. Agronomy 8(18):1-23. doi: 10.3390/agronomy8020018
Shukla MK, Lal R, Ebinger M. 2006. Determining soil quality indicators by factor analysis. Soil Tillage Research 87:194204.

Tabi FO, Ogunkunle AO. 2007. Spatial variation of some soil physico-chemical properties of an Alfisol in southwestern Nigeria. Nigerian Journal of Soil and Environmental Resources 7:82-91.

Tellen VA, Yerima BPK. 2018. Effects of land use change on soil physicochemical properties in selected areas in the North West region of Cameroon. Environmental Systems Research 7(3):1-29. doi.org/10.1186/s40068-018-0106-0

USDA, 2017. Soil quality kit, guide for educators. National resources conservation services. Retrieved from https://www.nrcs.usda.gov (accessed on 30/11/2020).

Voncir N, Mustapha S, Tenebe VA, Kumo AL, Kushwaha S. 2008. Content and profile distribution of extractable zinc ( $\mathrm{Zn})$ and some physicochemical properties of soil along a toposequence at Bauchi, Northern Guinea Savanna of Nigeria. International Journal of Soil Science 3:62-68.

Zotarelli T, Dukes MD, Morgan KT. 2019. Interpretation of Soil Moisture Content to Determine Soil Field Capacity and Avoid Over-Irrigating Sandy Soils Using Soil Moisture Sensors. UF/IFAS Extension document No. AE460, 2019. (accessed from: https://edis.ifas.ufl.edu on $27^{\text {th }}$ February, 2020) 